\title{
Mergulho no mar de informações da Web
}

Arquimedes Pessoni*

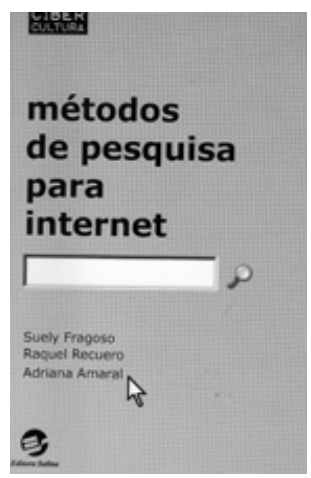

FRAGOSO, Suely; RECUERO, Raquel; AMARAL, Adriana. Métodos de pesquisa para a internet. Porto Alegre: Sulina, 2011. 239 p.

E

veio do sul uma das boas contribuições naquela que promete ser uma área promissora de pesquisa no segmento Comunicação deste século: a internet. As pesquisadoras Suely Fragoso (Universidade Federal do Rio Grande do Sul), Raquel Recuero (Universidade Católica de Pelotas) e Adriana Amaral (Universidade do Vale do Rio dos Sinos) são as responsáveis pela edição do livro Métodos de pesquisa para a internet (Porto Alegre: Sulina, 2011), que surge como um farol no mar de informações que os pesquisadores costumam navegar desde o advento da web. O livro chega como um desafio que alguém precisava assumir, haja vista que o tema é bem recente e sem receitas prontas. Escrever sobre uma área que ainda engatinha do ponto de vista acadêmico é como medir a temperatura e construir o termômetro, simultaneamente.

\footnotetext{
* Mestre e Doutor em Comunicação Social pela Universidade Metodista de São Paulo e docente titular do Programa de Pós-graduação em Comunicação da Universidade Municipal de São Caetano do Sul (USCS), São Caetano do Sul-SP, Brasil.
} 
Já na introdução, as autoras com ampla e atual pesquisa de referências bibliográficas internacionais deixam claro o tamanho do desafio, uma vez que a internet é ainda um lugar novo, onde muitos habitam. As pesquisadoras lembram que a rede mundial de computadores pode ser tanto objeto de pesquisa (aquilo que se estuda), quanto local de pesquisa (ambiente onde a pesquisa é realizada) e, ainda, instrumento de pesquisa (por exemplo, ferramenta para coleta de dados sobre um dado tema ou assunto). Foi na tentativa de dar conta dessas facetas, e de seu impacto para a pesquisa em geral, que as pesquisadoras optaram pela proposta de apresentar perspectivas metodológicas construídas para as problemáticas relativas à própria Comunicação mediada pela tecnologia digital e também fornecer subsídios para estudos sobre outros temas que sejam realizados na internet ou que a utilizem como instrumento de pesquisa (p.17-18).

Divididos em duas partes, a obra traz na primeira metade o panorama dos estudos da internet, a forma como se dá a construção de amostras e a importância da Teoria Fundamentada. É já nessa primeira parte do livro que as autoras lançam a questão sobre serem os estudos sobre internet uma disciplina ou campo. Apresentando os dois lados da moeda, as pesquisadoras optam por concentrar na noção de estudo de internet como campo de desenvolvimento - com suas contradições e especificidades - no qual podemos ajudar a ampliar e desenvolver tanto a pesquisa como o debate sobre o assunto (p.31).

É também na primeira parte do livro que as autoras sugerem possíveis temáticas o objetos de estudo na internet: linguagem, apropriação tecnológica, economia política da comunicação mediada por computador, ciberativismo, inclusão digital, práticas de consumo mercadológico e socialização online (p.47).

Mesmo com alguns escorregões na revisão de texto, como na página 57, na qual trocaram xeque por cheque (ainda em tempos de débito automático...) e o "iterativo" da página 70 , a riqueza do livro está nos olhares das pesquisadoras sobre o tema. Um dos aspectos que as deixam em estado de alerta é a questão da amostra nas pesquisas de internet. Segundo o trio gaúcho, o tamanho da amostra probabilística não pode ser definido de antemão, pois seria 
uma consequência das características do universo da pesquisa, dos métodos de seleção e recorte e do grau de generalização pretendido. As três vanguardistas do campo da netnografia acreditam que, independente do número de elementos que a compõem, qualquer amostra que não consegue abranger a variedade de casos relevantes encontrados no universo de pesquisa é muito pequena. (p.62-63).

$\mathrm{Na}$ segunda parte do livro, quando abordam as apropriações metodológicas, aí sim, as autoras nadam de braçada no mar do conhecimento: nesse momento fica claro, no livro, que a netnografia (net+etnografia) veio para ficar e terá seu valor devidamente reconhecido, mesmo para os dinossauros analógicos que ainda povoam a academia e torcem o nariz para mudanças.

Contando ainda um pouco de história da academia, as pesquisadoras explicam que do flerte entre as pesquisas de mercado e as acadêmicas surgiram outros termos como etnografia digital e webnografia, neologismos que, segundo alguns autores, deveriam estar sob o guarda chuva da ciberantropologia (p.176). De qualquer forma, nessa sopa de letrinhas, as autoras lembram que a análise das redes sociais é algo interdisciplinar, com conceitos desenvolvidos a partir do encontro da teoria social e da aplicação matemática formal, da estatística e dos métodos computacionais. Salientam, também, que este tipo de estudo tem um cunho estruturalista e parte do princípio que, ao estudar as estruturas decorrentes das ações e interações entre atores sociais é possível compreender elementos a respeito desses grupos e, igualmente, generalizações a seu respeito (p.115).

A sensação de quem termina a leitura do livro Métodos de pesquisa para a internet é de "quero mais". Isso porque o que foi escrito, mesmo sendo novo, ainda é pouco por conta desse campo imenso de estudos que foi aberto na comunicação com o advento da internet. Tudo que se escreve e pesquisa nessa área, em razão das inovações que não param de acontecer, parece obsoleto. A boa notícia está no fato desse ser o primeiro livro das autoras sobre o tema. Outros, com certeza, virão. Vamos compartilhar, curtir e retuitar essa dica de leitura. 
